\title{
Kualitas Keripik Bengkuang (Pachyrrhizus erosus (L.) Urb.) dengan Variasi Konsentrasi Ekstrak Bunga Rosela (Hibiscus sabdariffa Linn.)
}

\author{
The Quality of Yam Bean Chips with Various Consentrations of Rosella Flower (Hibiscus \\ sabdariffa Linn.)
}

\author{
Martina Setyasih, F. Sinung Pranata*, Ekawati Purwijantiningsih \\ Fakultas Teknobiologi, Universitas Atma Jaya Yogyakarta, Jl. Babarsari 44 Yogyakarta 55281 \\ E-mail: sinung@mail.uajy.ac.id *Penulis untuk korespondensi
}

\begin{abstract}
Yam bean chips have crispy texture and sweet taste. In this research, rosella extract is added in the mold of yam bean chips as natural preservaties, fiber and sources anthocyanin. The aim of this research is to know the effect of various consentrations of rosella extract on chips qualities. Research design utilized was randomized complete factorial design and the data compiled was treated by Anova and followed with Duncan's Multiple Range Test (DMRT) with degree of convidence 95\%. Chips with $0,67 \%$ rosella extract added has longer shelf life than chips with out rosella extract added. This Chips contain $0,59 \%$ water, $2,6 \%$ protein, $38,84 \%$ fat, $3,69 \%$ ash, $54,16 \%$ carbohydrate, $1,17 \mathrm{mg} / 100 \mathrm{~g}$ ascorbic acid, $1,4 \mathrm{mg} / \mathrm{l}$ anthocyanin, $1,17 \%$ acid total, $86,74 \%$ fiber crude, 53,47 level of lightness and total microorganism 30 CFU/G.
\end{abstract}

Key words: yam bean chips, extract rosella, natural preservaties

Diterima: 13 November 2007, disetujui: 22 Desember 2007

\section{Pendahuluan}

Keripik adalah makanan ringan (snack food) yang tergolong jenis makanan crackers yaitu makanan yang kering dan renyah (crispy). Sifat keripik yaitu renyah, tahan lama, praktis, mudah dibawa dan disimpan serta dapat dinikmati kapan saja. Renyah artinya keras tetapi mudah patah (Sofyan, 2004). Keripik dihasilkan dari pengeringan bahan pangan kemudian digoreng pada suhu tertentu. Tujuan pengeringan untuk mengurangi kadar air bahan pangan sampai batas mikroorganisme tidak dapat tumbuh lagi (Sarofa dan Latifah, 2002).

Pemanfaatan bengkuang menjadi keripik adalah salah satu alternatif diversifikasi olahan umbi dan memperpanjang umur simpan. Dengan demikian, bengkuang yang melimpah dan terbuang pada saat musim panen tetap dapat dimanfaatkan sehingga memiliki harga jual yang tinggi.
Pada penelitian ini ditambahkan ekstrak kelopak bunga rosela karena kandungan asam sitrat dan asam malat yang tinggi sehingga akan memperpanjang umur simpan keripik bengkuang. Asam sitrat dan asam malat berpotensi sebagai pengawet alami yang aman untuk digunakan dalam produk makanan maupun minuman (Sofyan, 2004).

\section{Metode Penelitian}

\section{Bahan}

Bahan yang digunakan adalah bengkuang yang diperoleh dari Pasar Giwangan, kelopak bunga rosela, minyak goreng, natrium metabisulfit, sukrosa, dan garam. Bahan kimia yang digunakan adalah larutan buffer potasium klorida $(0,025 \mathrm{M}) \mathrm{pH}$ 1, larutan buffer sodium asetat $(0,4 \mathrm{M}) \mathrm{pH} 4,5$, yodium $0,01 \mathrm{~N}$, amilum $1 \%, \mathrm{H}_{2} \mathrm{SO}_{4}$ pekat, $\mathrm{H}_{2} \mathrm{SO}_{4} 0,3 \mathrm{~N}$, indikator PP, Indikator MR, $\mathrm{HCl}$ 
0,1 N, aquadest, Petrolium Eter (PE), $\mathrm{NaOH} \mathrm{0,1}$ $\mathrm{N}$; medium Plate Count Agar (PCA), katalisator $\left(\mathrm{K}_{2} \mathrm{SO}_{4}+\mathrm{CuSO}_{4}\right)$, alkohol 95\% dan aseton.

\section{Rancangan percobaan dan analisis data}

Rancangan percobaan yang digunakan pada penelitian ini adalah Rancangan Acak Lengkap Faktorial. Faktor pertama yaitu variasi konsentrasi ekstrak rosela berupa $0 \%(\mathrm{~b} / \mathrm{v})$, 0,67\% (b/v) dan 1,3\% (b/v). Faktor kedua adalah waktu penyimpanan 0, 30, 60 hari. Data yang diperoleh dianalisis varians. Selanjutnya untuk mengetahui letak beda nyata dilakukan uji Duncan.

\section{Cara Kerja}

Tahapan penelitian yang dilakukan adalah: pembuatan ekstrak rosela, pembuatan keripik bengkuang dengan variasi konsentrasi ekstrak rosela, analisis parameter kualitas keripik bengkuang secara fisik (warna, tekstur); kimia (uji antosianin, vitamin C, serat, total asam, karbohidrat, protein, lemak, abu, dan kadar air); dan uji mikrobiologis (Angka Lempeng Total).

\section{Pembuatan ekstrak rosela}

Kelopak rosela kering dioven $\left(\mathrm{T}=60^{\circ}\right.$, $\mathrm{t}=45$ menit). Selanjutnya kelopak rosela diblender dan diayak 80 mesh. Bubuk rosela ditimbang sebanyak 10 dan 20 g, kemudian dimasukkan ke gelas beker yang berisi air hangat sebanyak $1500 \mathrm{ml}$. Larutan didiamkan selama 60 menit kemudian disaring dan ditambahkan sukrosa 100 g serta garam $10 \mathrm{~g}$.

\section{Pembuatan keripik bengkuang}

Bengkuang dipilih yang tidak rusak, lalu dikupas dan dicuci dengan air mengalir dan ditiriskan. Bengkuang diiris 3-4 mm menggunakan pengiris keripik manual selanjutnya ditimbang sebanyak $1000 \mathrm{~g}$ dan direndam dalam larutan natrium metabisulfit (1,4g dalam $1500 \mathrm{ml}$ air). Bengkuang ditiriskan dan direndam dalam larutan ekstrak rosela yang sudah ditambahkan $10 \mathrm{~g}$ garam dan $100 \mathrm{~g}$ sukrosa (10/20 g bubuk rosela kering dalam $1500 \mathrm{ml}$ air) selama 10 jam. Bengkuang ditiriskan dan digoreng menggunakan penggoreng hampa $\left(\mathrm{T}=90^{\circ} \mathrm{C}, \mathrm{t}=45\right.$ menit). Selanjutnya keripik bengkuang dikemas dalam alumunium foil kemudian direkatkan dengan mesin vakum sealer.

\section{Hasil dan Pembahasan}

\section{Kadar air}

Kadar air pada keripik bengkuang berbeda nyata antara kontrol dengan perlakuan, karena pada perlakuan bengkuang direndam extract rosela terjadi penyerapan air dan serat larut sehingga menyebabkan air yang terserap lebih banyak. Menurut Fenemma (2008), selama proses perendaman bahan akan mengalami hidrasi sehingga kadar air bengkuang akan naik dari kadar air bengkuang semula. Dengan demikian, semakin tinggi konsentrasi rosela yang ditambahkan maka kadar air keripik bengkuang semakin meningkat. Kadar air keripik bengkuang pada hari ke-0, 30, dan 60 menunjukkan beda nyata, tetapi hari ke-30 dengan 60 tidak berbeda nyata sebab kemampuan higroskopis keripik bengkuang sudah menurun (Gambar 1).

\section{Kadar abu}

Kadar abu keripik bengkuang berbeda nyata antara kontrol dengan perlakuan sebab rosela mengandung lebih banyak mineral dibandingkan dengan bengkuang. Kadar abu keripik bengkuang tanpa penambahan rosela sebesar 1,37\%, tetapi setelah ditambahkan rosela kadar abunya meningkat seiring dengan meningkatnya konsentrasi rosela yang diberikan (Gambar 2). Menurut Satuhu (1996), bengkuang mengandung kalsium $15 \mathrm{mg}$, fosfor $18 \mathrm{mg}$, dan besi 0,6 mg, sedangkan menurut Maryani dan Kristiana (2005), kelopak rosela mengandung mineral seperti kalsium $1.263 \mathrm{~g}$, fosfor 273,2 $\mathrm{mg}$ dan besi 8,98 $\mathrm{mg}$. Abu merupakan residu anorganik sisa dari pembakaran. Residu anorganik biasanya terdapat dalam bahan dalam bentuk senyawa seperti natrium, kalium, kalsium dan silika (Joslyn, 1970). Dengan demikian, semakin tinggi kadar abu pada keripik bengkuang, maka jumlah mineral yang masuk ke dalam jaringan meningkat. 


\section{Kadar lemak}

Kadar lemak pada keripik bengkuang berbeda nyata untuk setiap perlakuan (Gambar 3). Kadar lemak meningkat seiring meningkatnya konsentrasi rosela yang diberikan karena perendaman bengkuang ke dalam ekstrak rosela selama 10 jam menyebabkan kadar serat dan kadar air meningkat sehingga proses penggorengan semakin lama akibatnya minyak yang terserap ke dalam bahan semakin tinggi. Menurut Pratiwi et al., (2003), semakin lama dan semakin tinggi suhu menggoreng maka minyak yang terserap semakin tinggi, tetapi semakin tinggi suhu menggoreng maka bahan akan lebih cepat matang. Hal ini disebabkan selama menggoreng terjadi penguapan air pada bahan sehingga minyak terserap dan mengisi ruang kosong pada bahan yang pada mulanya diisi air.

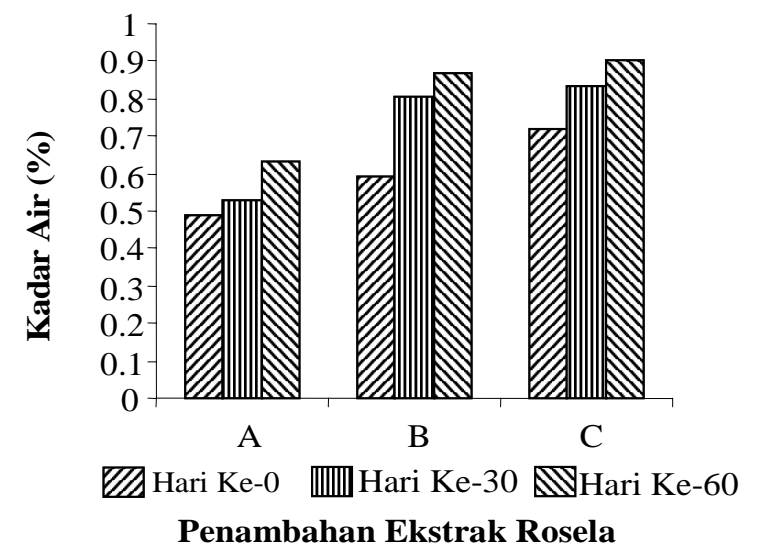

Gambar 1. Kadar air (\%) keripik bengkuang dengan variasi konsentrasi ekstrak rosela selama masa simpan

Keterangan : A = Penambahan ekstrak rosela $0 \%(\mathrm{~b} / \mathrm{v})$

$\mathrm{B}=$ Penambahan ekstrak rosela $0,67 \%(\mathrm{~b} / \mathrm{v})$

$\mathrm{C}=$ Penambahan ekstrak rosela 1,3\% (b/v)

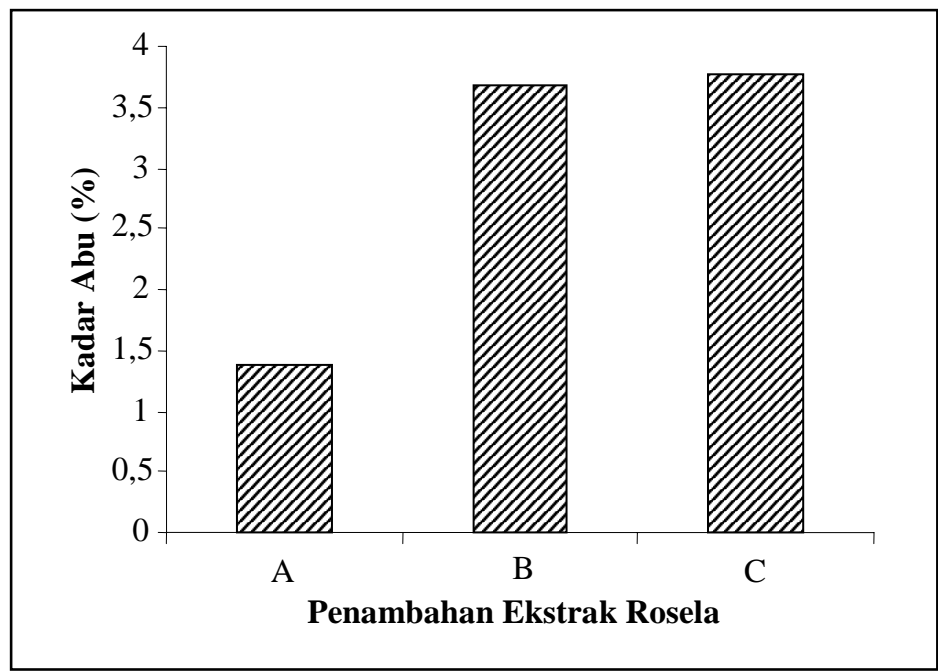

Gambar 2. Kadar abu (\%) pada keripik bengkuang dengan variasi konsentrasi ekstrak rosela

Keterangan : $\mathrm{A}=$ Penambahan ekstrak rosela $0 \%(\mathrm{~b} / \mathrm{v})$

$\mathrm{B}=$ Penambahan ekstrak rosela 0,67\% (b/v)

$\mathrm{C}=$ Penambahan ekstrak rosela 1,3\% (b/v) 


\section{Kadar protein}

Penambahan ekstrak rosela 20 g pada keripik bengkuang memberikan pengaruh yang nyata terhadap kadar protein sedangkan penambahan $10 \mathrm{~g}$ tidak berbeda nyata dengan perlakuan kontrol karena sebagian protein telah rusak saat penggorengan bengkuang pada suhu $90^{\circ} \mathrm{C}$ selama 45-60 menit (Gambar 4). Menurut Satuhu (1996), protein pada bengkuang yaitu 1,4 g, sedangkan menurut Maryani dan Kristiana (2005), kadar protein pada rosela kering 7,9\%. Dengan demikian, semakin tinggi rosela yang ditambahkan akan semakin meningkatkan kadar protein pada keripik bengkuang.

\section{Kadar karbohidrat}

Penambahan ekstrak rosela pada keripik bengkuang memberikan pengaruh yang berbeda nyata terhadap kadar karbohidrat untuk setiap perlakuan (Gambar 5). Kadar karbohidrat semakin menurun seiring dengan penambahan rosela, sebab rosela meningkatkan kadar protein, lemak, abu dan kadar air pada keripik bengkuang. Menurut Satuhu (1996), kadar karbohidrat pada bengkuang yaitu 12,8\%.

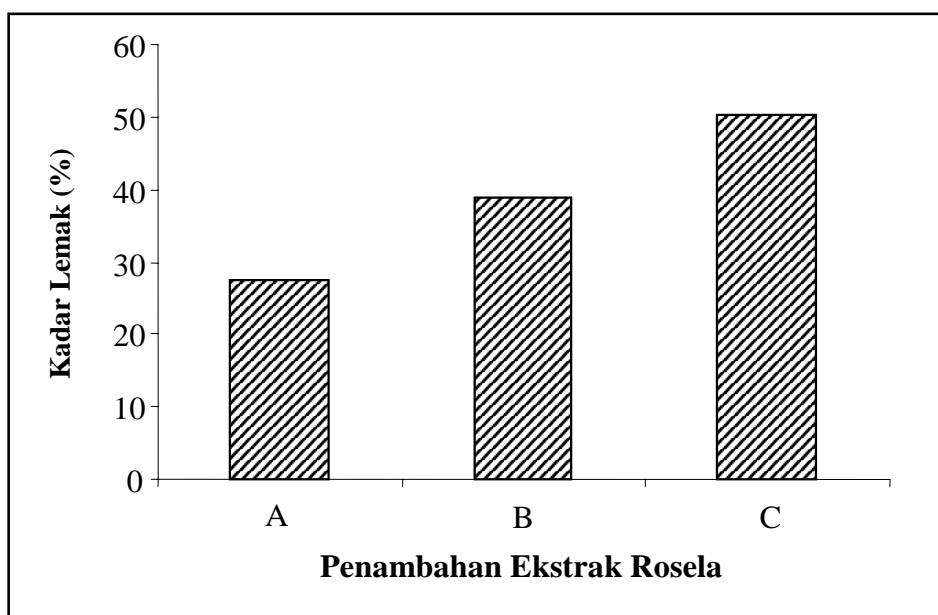

Gambar 3. Kadar lemak (\%) pada keripik bengkuang dengan variasi konsentrasi ekstrak rosela

Keterangan : $\mathrm{A}=$ Penambahan ekstrak rosela $0 \%(\mathrm{~b} / \mathrm{v})$

$\mathrm{B}=$ Penambahan ekstrak rosela $0,67 \%(\mathrm{~b} / \mathrm{v})$

$\mathrm{C}=$ Penambahan ekstrak rosela $1,3 \%(\mathrm{~b} / \mathrm{v})$

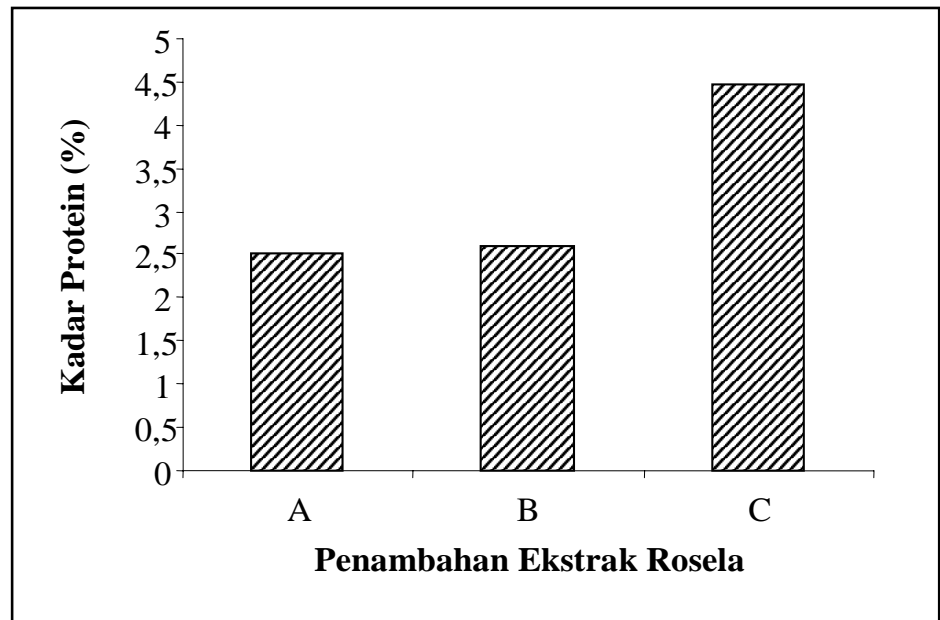

Gambar 4. Kadar protein (\%) pada keripik bengkuang dengan variasi konsentrasi ekstrak rosela

Keterangan : $\mathrm{A}=$ Penambahan ekstrak rosela $0 \%(\mathrm{~b} / \mathrm{v})$

$\mathrm{B}=$ Penambahan ekstrak rosela $0,67 \%(\mathrm{~b} / \mathrm{v})$

$\mathrm{C}=$ Penambahan ekstrak rosela 1,3\% (b/v) 


\section{Kadar vitamin C}

Pada Gambar 6 terlihat, penambahan ekstrak rosela tidak berpengaruh nyata terhadap kadar vitamin C pada keripik bengkuang. Semakin tinggi konsentrasi rosela yang diberikan kadar vitamin $\mathrm{C}$ semakin menurun sebab saat perendaman bengkuang ke dalam air rosela selama 10 jam mengakibatkan vitamin $\mathrm{C}$ yang terdapat pada bengkuang ikut terlarut ke dalam air tersebut. Menurut Winarno (2004), penurunan vitamin C ini karena vitamin C merupakan bahan yang bersifat hidrofilik yang mengandung banyak gugus hidroksilnya sehingga mudah berinteraksi dengan air. Selain itu, kadar air pada keripik bengkuang yang semakin tinggi seiring dengan meningkatnya konsentrasi rosela. Dengan demikian, reaksi hidrolisis vitamin $\mathrm{C}$ akan lebih efektif dengan bertambahnya kadar air akibatnya vitamin $\mathrm{C}$ semakin menurun. Penurunan vitamin $C$ juga disebabkan terjadinya reaksi oksidasi saat pengirisan bengkuang menggunakan pisau.

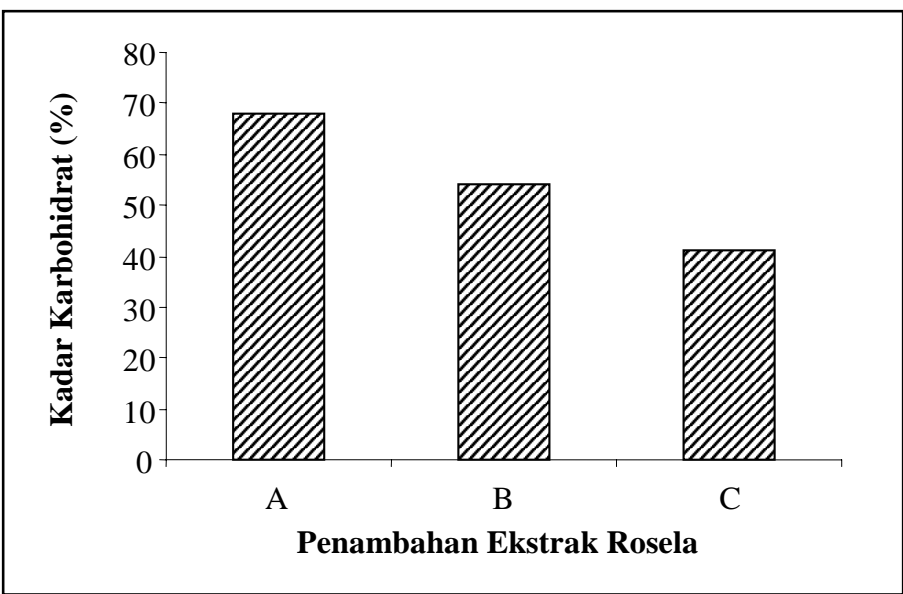

Gambar 5. Kadar karbohidrat (\%) pada keripik bengkuang dengan variasi konsentrasi ekstrak rosela

Keterangan : $\mathrm{A}=$ Penambahan ekstrak rosela $0 \%(\mathrm{~b} / \mathrm{v})$

$\mathrm{B}=$ Penambahan ekstrak rosela $0,67 \%(\mathrm{~b} / \mathrm{v})$

$\mathrm{C}=$ Penambahan ekstrak rosela 1,3\% (b/v)

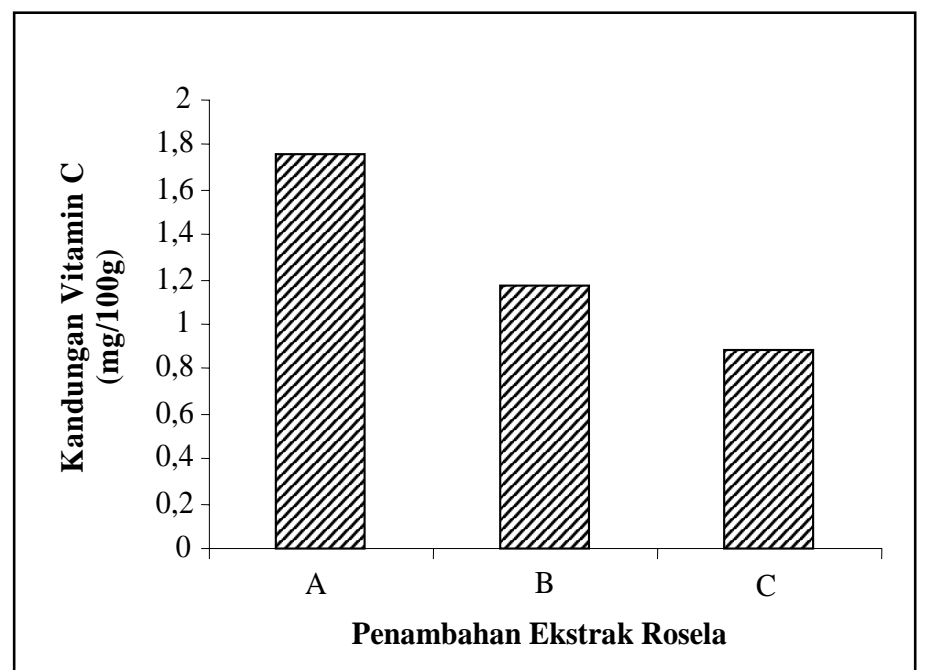

Gambar 6. Kadar vitamin C (mg/100g) pada keripik bengkuang dengan variasi konsentrasi ekstrak rosela

Keterangan : $\mathrm{A}=$ Penambahan ekstrak rosela $0 \%(\mathrm{~b} / \mathrm{v})$

$\mathrm{B}=$ Penambahan ekstrak rosela $0,67 \%(\mathrm{~b} / \mathrm{v})$

$\mathrm{C}=$ Penambahan ekstrak rosela 1,3\% (b/v) 


\section{Kadar antosianin}

Penambahan ekstrak rosela berpengaruh nyata terhadap kadar antosianin pada keripik bengkuang (Gambar 7). Semakin tinggi konsentrasi rosela yang diberikan kadar antosianin semakin meningkat. Keripik bengkuang yang tidak ditambah dengan rosela tidak mengandung antosianin karena warna keripik tidak merah. Menurut Markakis (1982) dalam Hastuti et al., (2006), menurunnya stabilitas warna antosianin karena suhu yang tinggi disebabkan terjadinya dekomposisi antosianin dari bentuk aglikon menjadi kalkon (tidak berwana) dan akhirnya membentuk alfa diketon yang berwarna coklat.

\section{Kadar total asam}

Penambahan ekstrak rosela berpengaruh nyata terhadap kadar total asam pada keripik bengkuang (Gambar 8). Semakin tinggi konsentrasi rosela yang diberikan total asamnya semakin meningkat. Tinggi rendahnya kadar total asam pada keripik ini ditentukan oleh $\mathrm{pH}$ dari rosela dan kepekatan larutan rosela yang digunakan untuk merendam bengkuang. Derajat keasaman pada rosela 3,14 artinya asam. Menurut Maryani dan Kristiana (2005), jenis asam yang terdapat pada rosela yaitu campuran asam sitrat dan asam malat berjumlah $13 \%$.

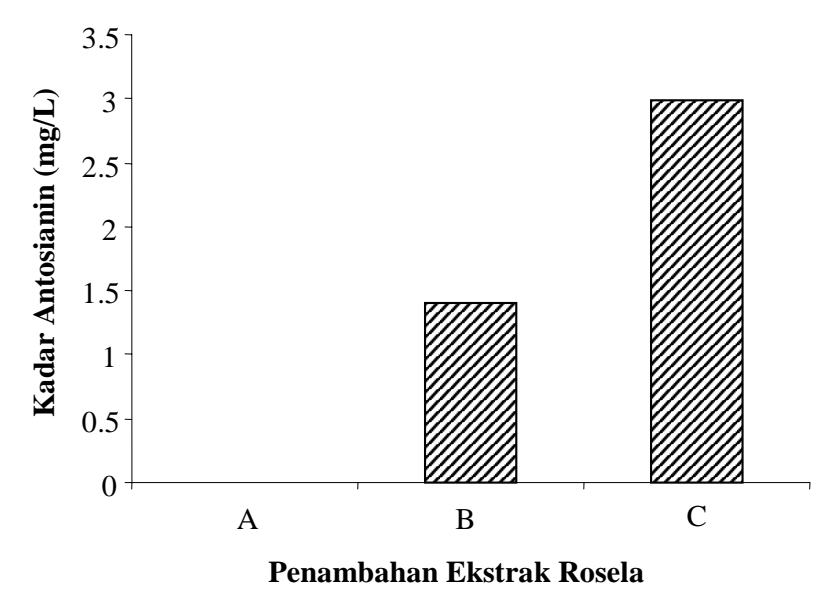

Gambar 7. Kadar antosianin (mg/L) pada keripik bengkuang dengan variasi konsentrasi ekstrak rosela

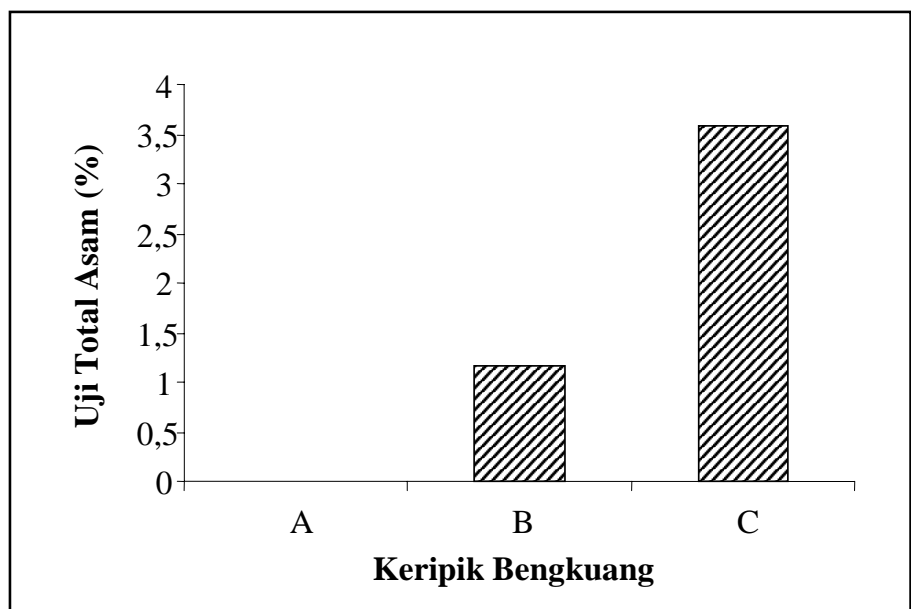

Gambar 8. Kadar total asam (\%) pada keripik bengkuang dengan variasi konsentrasi ekstrak rosela

Keterangan : $\mathrm{A}=$ Penambahan ekstrak rosela 0\% (b/v)

$\mathrm{B}=$ Penambahan ekstrak rosela $0,67 \%(\mathrm{~b} / \mathrm{v})$

$\mathrm{C}=$ Penambahan ekstrak rosela 1,3\% (b/v) 
Asam sitrat $\left(\mathrm{C}_{6} \mathrm{H}_{8} \mathrm{O}_{7}\right)$ merupakan asam organik lemah dan berfungsi sebagai bahan pengawet yang baik dan alami untuk makanan dan minuman, serta penambah rasa masam. Asam sitrat sebagai larutan penyangga, dapat mengendalikan $\mathrm{pH}$ larutan dan dapat bereaksi dengan ion-ion logam dengan pengkhelatan sehingga dapat untuk pengawet dan penghilang kesadahan air. Hal ini sesuai penelitian Pranata (2003) yaitu asam askorbat (5\%) sebagai asam organik dapat memperpanjang umur simpan apel potong segar.

Kualitas keripik bengkuang secara mikrobiologis semakin baik jika kadar total asamnya semakin tinggi karena kondisi asam dapat memperpanjang umur simpan. Menurut Trenggono dan Setiajadi (1990), kerja asam sebagai bahan pengawet tergantung pada pengaruhnya terhadap pertumbuhan mikroorganisme seperti bakteri, kamir dan kapang yang tumbuh pada bahan makanan. Penambahan asam berarti menurunkan $\mathrm{pH}$ yang disertai dengan naiknya konsentrasi ion hidrogen $\left(\mathrm{H}^{+}\right)$dan $\mathrm{pH}$ rendah lebih besar penghambatannya pada pertumbuhan mikroorganisme. Asam digunakan sebagai pengatur $\mathrm{pH}$ sampai pada harga yang bersifat toksis untuk mikroorganisme dalam bahan makanan.

\section{Kadar serat kasar}

Penambahan ekstrak rosela berpengaruh nyata terhadap kadar serat pada keripik bengkuang (Gambar 9). Menurut Nurman (2008), rosela mengandung serat larut air sebanyak 33,9\%. Kadar serat pada keripik bengkuang berpengaruh nyata terhadap tinggi rendahnya kadar air, kadar lemak serta kerenyahan tekstur pada produk tersebut. Serat bersifat menyerap air maka kadar air keripik semakin tinggi sehingga produk semakin tidak renyah dan kadar lemaknya juga akan meningkat karena membutuhkan waktu yang lebih lama untuk menguapkan air akibatnya minyak yang terserap lebih banyak.

\section{Uji warna}

Penambahan ekstrak rosela berpengaruh nyata terhadap kadar warna pada keripik bengkuang. Semakin tinggi konsentrasi rosela yang ditambahkan tingkat kecerahan (lightness) keripik bengkuang akan semakin menurun karena warna keripik bengkuang semakin merah (Gambar 10). Perubahan warna pada keripik bengkuang disebabkan karena terjadinya reaksi maillard yaitu reaksi antara gugus amino primer dengan gula pereduksi yang menghasilkan bahan berwarna coklat.

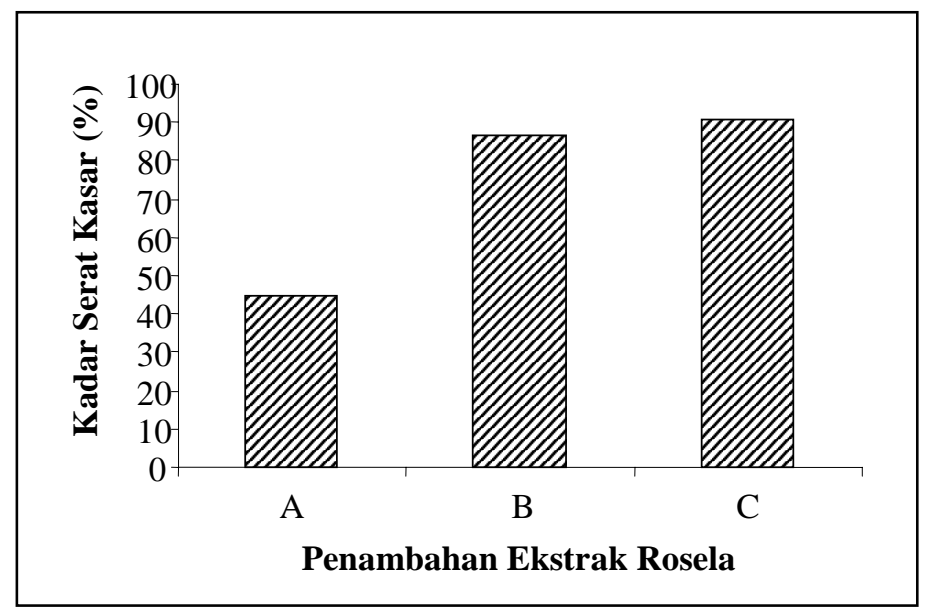

Gambar 9. Kadar serat (\%) pada keripik bengkuang dengan variasi konsentrasi ekstrak rosela

Keterangan : $\mathrm{A}=$ Penambahan ekstrak rosela 0\% (b/v)

$\mathrm{B}=$ Penambahan ekstrak rosela $0,67 \%(\mathrm{~b} / \mathrm{v})$

$\mathrm{C}=$ Penambahan ekstrak rosela 1,3\% (b/v) 


\section{Uji tekstur}

Penambahan ekstrak rosela berpengaruh nyata terhadap keripik bengkuang (Gambar 11). Semakin tinggi konsentrasi rosela yang ditambahkan tekstur keripik bengkuang akan semakin menurun karena rosela mengandung serat yang tinggi sehingga keripik yang dihasilkan kurang renyah atau liat sebab serat akan mengikat air. Selain itu, perendaman irisan bengkuang selama 10 jam mengakibatkan kadar air semakin tinggi sehingga keripik yang dihasilkan kurang renyah.

\section{Analisis mikroorganisme (Angka lempeng total)}

Penambahan ekstrak rosela berpengaruh nyata terhadap jumlah total mikroorganisme pada keripik bengkuang selama umur simpan (Gambar 12). Penambahan rosela $10 \mathrm{~g}$ dan $20 \mathrm{~g}$ tidak berbeda nyata terhadap jumlah mikroorganisme. Pertumbuhan mikroorganisme sangat sensitif terhadap perubahan $\mathrm{pH}$ sehingga pada perlakuan $10 \mathrm{~g}$ rosela, pertumbuhan bakteri sudah terhambat. Semakin tinggi konsentrasi rosela yang ditambah, maka jumlah mikroorganisme semakin sedikit karena rosela mengandung asam sitrat dan asam malat yang tinggi akibatnya pertumbuhan bakteri terhambat. Menurut Nurfaridah (2007), tingkat keasaman rosela mencapai 3,14 sedangkan mikroorganisme pada umumnya tumbuh optimal pada $\mathrm{pH}$ netral yaitu 7.

Jumlah mikroorganisme semakin meningkat seiring bertambahnya umur simpan keripik bengkuang. Jumlah mikroorganisme tertinggi yaitu pada perlakuan kontrol dengan nilai 112 CFU/g sebab keripik bengkuang tidak ditambahkan asam sitrat dan asam malat yang berasal dari ekstrak kelopak bunga rosela. Keripik bengkuang yang divariasi dengan rosela jumlah rata-rata bakterinya hanya 30 sehingga memiliki umur simpan lebih lama.

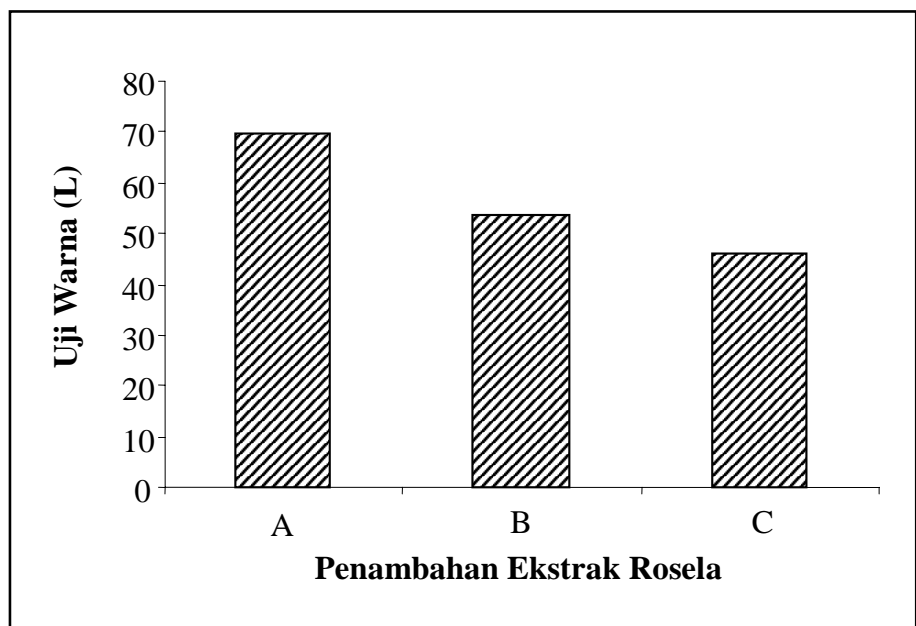

Gambar 10. Uji warna (L) pada keripik bengkuang dengan variasi konsentrasi ekstrak rosela

Keterangan : $\mathrm{A}=$ Penambahan ekstrak rosela $0 \%(\mathrm{~b} / \mathrm{v})$

$\mathrm{B}=$ Penambahan ekstrak rosela $0,67 \%(\mathrm{~b} / \mathrm{v})$

$\mathrm{C}=$ Penambahan ekstrak rosela 1,3\% (b/v) 


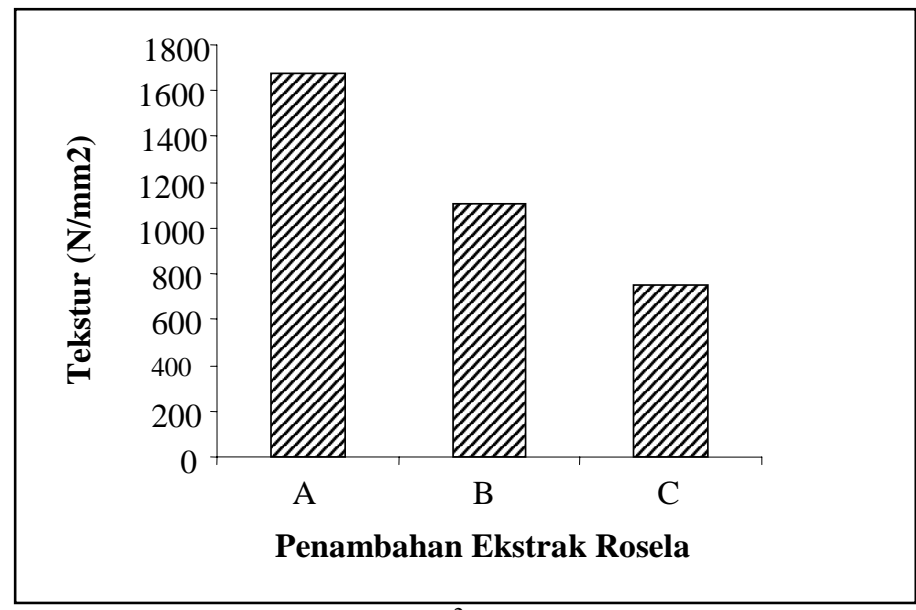

Gambar 11. Uji tekstur $\left(\mathrm{N} / \mathrm{mm}^{2}\right)$ pada keripik dengan bengkuang variasi konsentrasi ekstrak rosela

Keterangan : $\mathrm{A}=$ Penambahan ekstrak rosela $0 \%(\mathrm{~b} / \mathrm{v})$

$\mathrm{B}=$ Penambahan ekstrak rosela $0,67 \%(\mathrm{~b} / \mathrm{v})$

$\mathrm{C}=$ Penambahan ekstrak rosela $1,3 \%(\mathrm{~b} / \mathrm{v})$

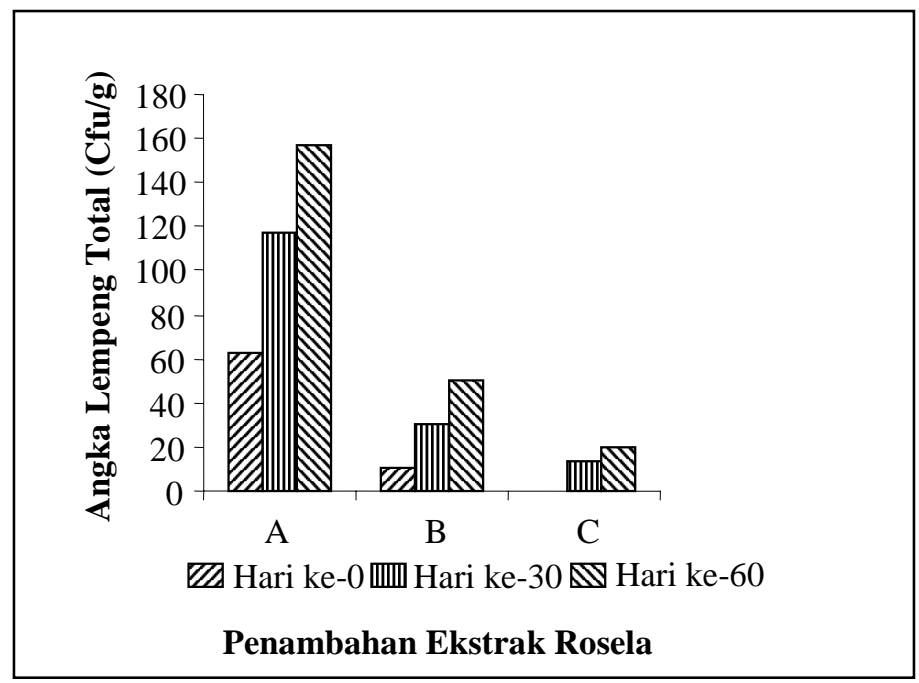

Gambar 12. Angka lempeng total (CFU/g) pada keripik bengkuang dengan variasi konsentrasi ekstrak rosela selama masa simpan

Keterangan : $\mathrm{A}=$ Penambahan ekstrak rosela $0 \%(\mathrm{~b} / \mathrm{v})$

$\mathrm{B}=$ Penambahan ekstrak rosela $0,67 \%(\mathrm{~b} / \mathrm{v})$

$\mathrm{C}=$ Penambahan ekstrak rosela $1,3 \%(\mathrm{~b} / \mathrm{v})$

\section{Kesimpulan}

Penambahan ekstrak rosela meningkatkan kadar air, protein, lemak, abu, serat, total asam, dan antosianin, tetapi menurunkan kadar vitamin $\mathrm{C}$, karbohidrat, dan tekstur pada keripik bengkuang. Keripik bengkuang yang ditambah ekstrak rosela umur simpannya lebih lama dibandingkan dengan kontrol, karena rosela mengandung asam sitrat dan asam malat yang berfungsi sebagai pengawet alami.

\section{Ucapan Terima Kasih}

Peneliti mengucapkan terima kasih kepada Bapak Wisnu Trisno Widayat yang membantu penelitian di Laboratorium Teknobio Pangan Fakultas Teknobiologi Universitas Atma Jaya Yogyakarta. 


\section{Daftar Pustaka}

Fenemma, O.R. 2008. Principles of Food Science. Food Chemistry, Marcel Dekker Inc. New York.

Hastuti, P., Indrasari, R. dan Anggrahini, S. 2006. Anthosianin Bunga Teleng (Clitoria ternatea L.): Ekstraksi dan Kerusakannya dalam Pemanasan. Sem. Nas. PATPI.

Joslyn, M.A. 1970. Method in Food Analysis. Academic Press Inc. New York.

Maryani, H. dan Kristiana, L. 2005. Khasiat dan Manfaat Rosela. PT Agromedia Pustaka. Tangerang.

Nurfaridah, D. 2007. Karena Merah Berarti Khasiat. Majalah Trubus 455: 121.

Nurman, I. 2008. Obat Tradisional. Majalah Trubus 460: 117.

Pranata, F.S. 2003. Aplikasi Coat dan Film Pati Batang Aren untuk Mencegah Susut Berat dan Pencoklatan pada Buah Apel Terolah Minimal. Biota 8 (3): 115-116.

Pratiwi, I.A.R., Rahardjo, B., Suhargo dan Marsono, Y. 2003. Kajian Kinetika Tekstur dan Serapan Minyak Pada Kentang Selama Penggorengan. Sem. Nas. PATPI. Yogyakarta.
Sarofa, U. dan Latifah. 2002. Pembuatan Keripik Sirsak dengan Perendaman Larutan $\mathrm{CaCl}_{2}$ dan Madu. Sem. Nas. PATPI. Malang.

Satuhu. 1996. Penanganan dan Pengolahan Buah. Penebar Swadaya. Jakarta.

Sofyan, H.M.I. 2004. Mempelajari Pengaruh Ketebalan Irisan dan Suhu Penggorengan Secara Vakum Terhadap Karakteristik Keripik Melon. Fakultas Teknik-Universitas Pasundan. Infomatek 6 (3): 162.

Trenggono, B. dan Setiadji. 1990. Biokimia Pangan. Pusat Antara Universitas Pangan dan Gizi. Universitas Gadjah Mada, Yogyakarta.

Winarno, F.G. 2004. Kimia Pangan dan Gizi. PT Gramedia. Jakarta. 